\title{
A mighty khatun
}

S. Lalani $\mathrm{MPH}$

\author{
A graceful lady limped \\ in Jinnah's outpatient clinic, \\ manicured toes \\ tucked in black chappals. \\ Body seated \\ on a wooden bench, \\ a calm and dainty woman. \\ Thick spectacles rested \\ on her slender nose. \\ Lesions dotted \\ her PET scan, \\ hijacking her body \\ like a band of \\ malicious pirates. \\ She bravely stood \\ clasping my hand, \\ as I wondered how \\ to grasp that moment \\ when her inner strength triumphed \\ and her saffron dupatta shimmered, \\ in the rays of Karachi's splendid sun.
}

\section{COMMENTARY}

The subject in this poem is my mother, Dr. Fatima Hashamali, a dedicated pediatrician and a humanitarian who lived her life serving some of the world's poorest children in Kenya, Tanzania, and Pakistan. Through her short cancer journey, she was always calm and composed, often helping the sick and the destitute despite her own pain and illness. She embodied the word "grace."

\begin{tabular}{ll}
\hline & \multicolumn{1}{c}{ GLOSSARY } \\
\hline Khatun & An Urdu word referring to a woman. \\
Jinnah & Refers to Jinnah Postgraduate Medical Centre. \\
Chappal & A type of sandal. \\
Dupatta & $\begin{array}{l}\text { A long scarf worn over many South Asian } \\
\text { women's outfits. }\end{array}$ \\
\hline
\end{tabular}

